\title{
PENGARUH DANA PERIMBANGAN DAN PENDAPATAN ASLI DAERAH TERHADAP BELANJA DAERAH PEMERINTAH KABUPATEN DAN KOTA DI JAWA TIMUR
}

\author{
Oleh: \\ Poppy Eliza Ritmadanti Jatmiko \\ Suzuki Indomobil Malang \\ E-mail: poppyelizarj@gmail.com
}

\begin{abstract}
The purpose of this research is to determine the influence of equalization funds and local own-source revenues to district and city Government expenditure of East Java. The analysis tool used is regression panel data, regression estimation method selected is using Fixed Effect method. The results of analysis stated that the two variables, namely the equalization fund and local revenue positive effect on district and city Government expenditure of East Java. Although the fund balance positive influence on shopping areas, but cause a regional equalization funds can not be independent, since they rely on the central government. Whereas in the autonomous regions, each region are urged to maximize local revenue for local revenue is a reflection of the independence of a region. The higher contribution of the local revenue of the local revenue, the level of independence of a region is getting higher and higher contributions fund the balance of the local revenue, the level of independence of a region lower, which means dependence on the central government area is high.
\end{abstract}

Keywords: Balance Fund, Local Own-source Revenue, Government Expenditures.

\begin{abstract}
Abstrak
Tujuan penelitian ini adalah untuk mengetahui pengaruh dana perimbangan dan pendapatan asli daerah terhadap belanja daerah pemerintah kabupaen dan kota di Jawa Timur. Alat analisis yang digunakan adalah regresi data panel. Metode estimasi regresi yang terpilih adalah menggunakan metode Fixed Effect. Hasil analisis menyatakan bahwa kedua variabel yaitu dana perimbangan dan pendapatan asli daerah berpengaruh signifikan positif terhadap belanja daerah pemerintah kabupaen dan kota di Jawa Timur. Meskipun dana perimbangan berpengaruh positif terhadap belanja daerah, akan tetapi dana perimbangan menyebabkan suatu daerah tidak bisa mandiri, karena masih menggantungkan pada pemerintah pusat. Sedangkan dalam otonomi daerah, masing-masing daerah dihimbau agar dapat memaksimalkan pendapatan asli daerahnya karena pendapatan asli daerah merupakan cerminan dari kemandirian suatu daerah. Semakin tinggi kontribusi pendapatan asli daerah terhadap penerimaan daerah, maka tingkat kemandirian suatu daerah semakin tinggi dan semakin tinggi kontribusi dana perimbangan terhadap penerimaan daerah, maka tingkat kemandirian suatu daerah semakin rendah, yang artinya ketergantungan daerah terhadap pemerintah pusat tinggi.
\end{abstract}

Kata kunci: Dana Perimbangan, Pendapatan Asli Daerah, Belanja Daerah. 


\section{PENDAHULUAN}

Dengan diberlakukannya UU No.32 tahun 2004 tentang pemerintahan daerah, maka setiap daerah diberikan kewenangan atau kebebasan dalam mengatur dan mengurus daerahnya sendiri sesuai dengan perundang-undangan yang berlaku atau yang disebut dengan desentralisasi. Hal ini tentunya menjadi kesempatan yang baik bagi pemerintah daerah untuk menggali kemampuan daerahnya, dalam hal ini pemerintah daerah diharapkan dapat meningkatkan kemampuannya dalam melaksanakan pembangunan dengan cara menggali sumbersumber potensial yang berada di daerah. Sumber-sumber potensial tersebut disebut dengan nama Pendapatan Asli Daerah.

Apabila dana yang digunakan untuk membangun daerah lebih besar diambil dari pendapatan asli daerah dibandingkan dengan dana perimbangan dari pemerintah pusat, maka daerah tersebut adalah daerah yang mandiri, dan sebaliknya apabila kontribusi pendapatan asli daerah lebih kecil daripada dana perimbangan, maka daerah tersebut termasuk dalam kategori daerah yang belum mandiri.

Tuasikal (2008) sejak diberlakukan reformasi keuangan daerah dan sejalan dengan implementasi otonomi daerah tampak bahwa sejumlah daerah tertentu tidak mampu membiayai rumah tangga daerahnya sendiri sebagai akibat dari kapasitas fiskal yang rendah. Struktur belanja setiap pemerintah daerah perlu diperkuat agar dapat mendorong pertekonomian daerah.

Semakin tinggi dana perimbangan dari pemeritah pusat dan pendapatan asli daerah, maka akan menambah nilai belanja dari pemerintah daerah, dan sebaliknya semakin kecil dana perimbangan yang diberikan pemerintah pusat kepada pemerintah daerah serta semakin kecil perolehan pendapatan asli daerah, maka akan mengurangi belanja pemerintah daerah. 
UU No 33 Tahun 2004 menjabarkan tujuan dari dana perimbangan adalah untuk mengurangi kesenjangan fiskal antara pemerintah pusat dengan pemerintah daerah serta pemerintah antar daerah guna tercapai adanya pemerataan pembangunan.

Dalam publikasi yang diterbitkan DJPK dengan judul Deskripsi dan Analisis APBD 2011, PAD tertinggi dicapai oleh Pemerintah Provinsi Jawa Timur sebesar $76,9 \%$ dan terendah dimiliki oleh Pemerintah Provinsi Papua Barat sebesar 2,9\%. Sebaliknya, transfer tertinggi terhadap total pendapatan adalah provinsi papua barat sebesar 97,5\% dan terendah adalah provinsi Jawa Timur sebesar 22,9\%. Data tersebut dapat dilihat dari gambar berikut.

\section{Gambar 1. Rasio Kemandirian Pemerintah Provinsi}

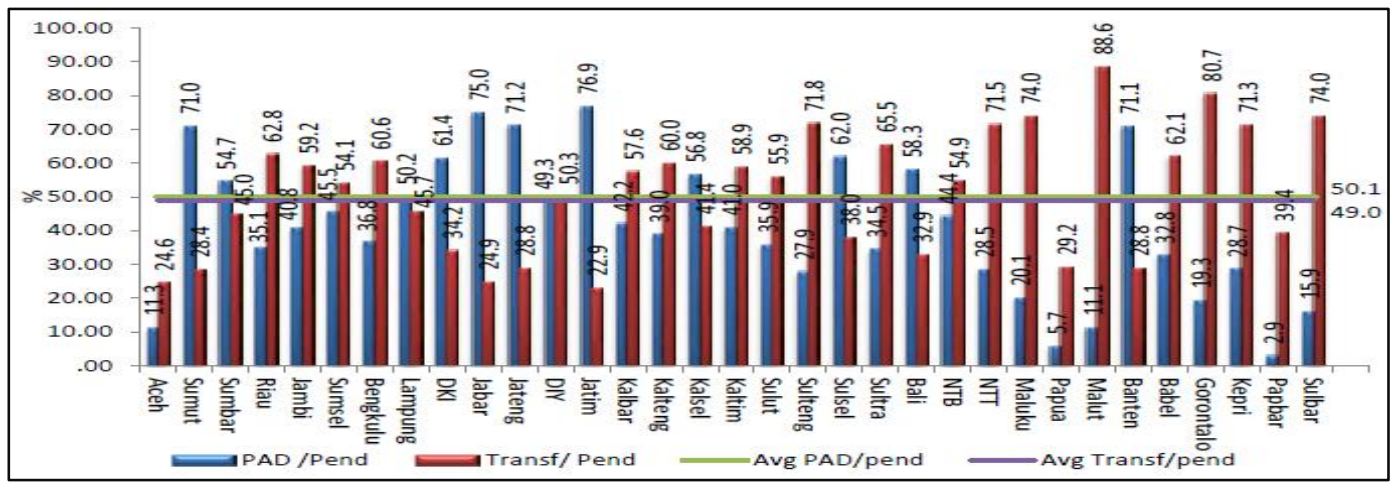

Sumber : Direktorat Jenderal Perimbangan Keuangan, 2016.

Semakin tinggi rasio PAD

dan semakin rendah transfer menunjukkan bahwa daerah tersebut semakin mandiri, dan sebaliknya senakin rendah rasio PAD dan semakin tinggi transfer makan menunjukkan daerah tersebut belum mandiri.

Meskipun pemerintah

Provinsi Jawa Timur pada tahun 2011 mempunyai rasio kemandirian pemerintah Provinsi tertinggi, akan tetapi rasio kemandirian pemerintah kabupaten/kota se Provinsi Jawa Timur masih rendah jika dibandingkan dengan Bali, Banten, Kepulauan Riau dan Daerah Istimewa Yogyakarta. Pada tahun 2011 yakni hanya sebesar 13,4\%.

Data tersebut bisa dilihat dalam gambar berikut. 
Gambar 2. Rasio kemandirian pemerintah kabupaten dan kota se Provinsi

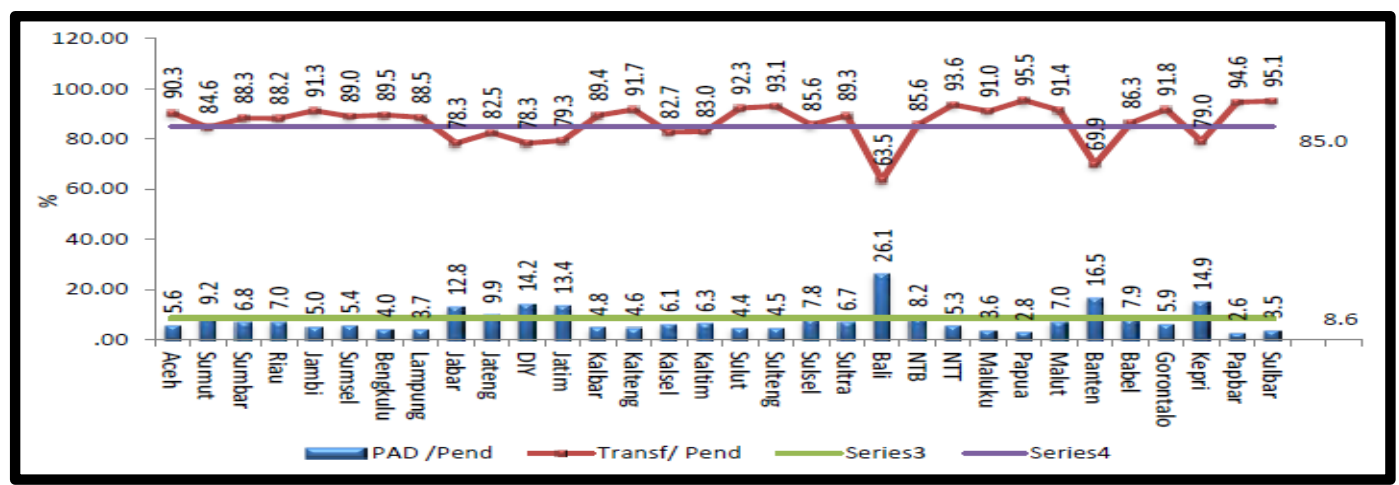

Sumber : Direktorat Jenderal Perimbangan Keuangan, 2016.

Budiarti (2014), juga

menjelaskan bahwa rata-rata pendapatan asli daerah Jawa Timur pada tahun 2010-2013 masih dibawah $15 \%$, meskipun pendapatan asli daerah mengalami peningkatan disetiap tahunnya, tetapi pendapatan asli daerah belum mampu untuk membiayai semua komponen belanja daerah. Ketidakmampuan pendapatan asli daerah dalam membiayai semua komponen belanja daerah disebabkan oleh masih kurangnya pengelolaan sumber daya atau kekayaan yang menjadi komponen pendapatan asli daerah yang ada di daerah. Sedangkan dana alokasi umum masih memiliki pengaruh yang sangat besar terhadap belanja daerah. Meskipun dana alokasi umum dari tahun 2010-2013 mengalami penurunan, tetapi kontribusi dana alokasi umum ke daerah masih tinggi yaitu diatas $50 \%$.

Penelitian ini dilakukan untuk mengetahui Pengaruh Dana Perimbangan dan Pendapatan Asli Daerah Terhadap Belanja Daerah Pemerintah Jawa Timur pada tahun 2012-2014.

\section{METODE PENELITIAN}

Lokasi penelitian yang digunakan dalam penyusunan penelitian ini adalah di 38 kabupaten/kota yang ada di Jawa Timur dengan menggunakan alat analisis regresi data panel 
menggunakan metode fixed effect. Metode fixed effect mengasumsikan bahwa perbedaan antar individu dapat diakomodasi dari perbedaan intersepnya, namun demikian slopnya sama antar variabel. Model estimasi ini menggunakan teknik Least Squares Dummy Variable (LSDV). Jenis penelitian yang digunakan adalah deskriptif kuantitatif yaitu metode analisa data dengan menggunakan data dalam bentuk angka-angka atau nilai dari bentuk data kemudian dianalisa dengan menambahkan keterangan berupa kalimat-kalimat untuk menerangkan data kuantitatif. Sumber data di peroleh dari website Direktorat Jenderal Perimbangan Keuangan (DJPK) Kementerian Keuangan RI yang telah dipublikasikan.

\section{Definisi}

Operasional

Variabel: Variabel dependen merupakan variabel terikat, dimana dalam penelitian ini digunakan adalah belanja daerah. Belanja daerah adalah pengeluaran pemerintah daerah dalam suatu periode tertentu. variabel bebas atau variabel independent dalam penelitian ini terdapat 2 (dua) variabel yaitu dana perimbangan dan pendapatan asli daerah. Dana Perimbangan $\left(\mathrm{X}_{1}\right)$ adalah dana yang diberikan oleh pemerintah pusat yang diperuntukkan bagi pemerintah daerah dan diambil dari APBN dalam rangka desentralisasi. Dana perimbangan meliputi dana bagi hasil (DBH), dana alokasi umum (DAU) dan dana alokasi khusus (DAK). Pendapatan Asli Daerah $\left(\mathrm{X}_{2}\right)$ adalah pendapatan yang asli dihasilkan oleh suatu daerah, pendapatan asli daerah terdiri dari empat komponen yaitu pajak daerah, retribusi daerah, hasil pengelolaan kekayaan daerah yang dipisahkan, lain-lain PAD yang sah.

\section{PEMBAHASAN}

Dana perimbangan sangat berperan terhadap pembangunan pemerintah kabupaten/kota yang ada di Jawa Timur, karena jumlahnya lebih dari $65 \%$ dari total penerimaan daerah, meskipun dari segi kontribusi terhadap penerimaan daerah persentase kontribusi dana perimbangan menurun,namun jumlah dana perimbangan yang diterima selalu naik dari tahun ke tahunnya 
(2012-2014). Berikut adalah tabel persentase dana perimbangan, pendapatan asli daerah dan lain-lain pendapatan daerah yang sah terhadap total penerimaan daerah kabupaten dan kota di Jawa Timur tahun 20122014.

Tabel 1. Persentase dana perimbangan, pendapatan asli daerah dan lain-lain pendapatan daerah yang sah terhadap total penerimaan daerah kabupaten dan kota di Jawa Timur tahun 2012-2014 (dalam juta rupiah)

\begin{tabular}{cccccccc}
\hline \multirow{2}{*}{ Tahun } & $\begin{array}{c}\text { Total } \\
\text { Penerimaan }\end{array}$ & $\begin{array}{c}\text { Dana } \\
\text { Perimbangan }\end{array}$ & $\begin{array}{c}\text { Kontri- } \\
\text { busi } \\
(\%)\end{array}$ & PAD & $\begin{array}{c}\text { Kontri- } \\
\text { busi } \\
(\%)\end{array}$ & $\begin{array}{c}\text { Lain-lain } \\
\text { pendapatan } \\
\text { daerah } \\
\text { yang sah }\end{array}$ & $\begin{array}{c}\text { Kontri- } \\
\text { busi } \\
(\%)\end{array}$ \\
\hline 2012 & 46.171 .605 & 32.863 .727 & 71,18 & 6.298 .206 & 13,64 & 7.009 .673 & 15,18 \\
\hline 2013 & 52.851 .006 & 36.734 .736 & 69,51 & 7.672 .763 & 14,52 & 8.443 .507 & 15,97 \\
\hline 2014 & 61.057 .922 & 39.860 .385 & 65,28 & 9.875 .582 & 16,17 & 11.321 .955 & 18,55 \\
\hline
\end{tabular}

Sumber: Data Pendapatan Daerah Jawa Timur, DJPK tahun 2012-2014, data diolah.

Dari tabel persentase dana perimbangan, pendapatan asli daerah dan lain-lain pendapatan daerah yang sah terhadap total penerimaan kabupaten dan kota di Jawa Timur tahun 2012-2014 dapat diketahui bahwa persentase dana perimbangan terhadap total penerimaan kabupaten dan kota di Jawa Timur selalu lebih dari $65 \%$ bahkan tahun 2012 jumlahnya lebih dari $70 \%$ dari total pendapatan, sedangkan sumbangan pendapatan asli daerah masih sangat kecil apabila dibandingkan dengan total penerimaan kabupaten dan kota di Jawa Timur, yaitu hanya antara 14-16\% pada tahun 2012-2014. Karena pendapatan asli daerah kabupaten dan kota di Jawa Timur belum mampu memenuhi semua kebutuhan belanja daerahnya, oleh karena itu diberikanlah dana perimbangan dari pemerintah pusat kepada pemerintah kabupaten dan kota di Jawa Timur yang jumlahnya berbeda-beda untuk setiap kabupaten/kota.

Kabupaten dan kota dengan persentase kenaikan dana perimbangan tertinggi dan terendah 
di Jawa Timur tahun 2012-2014

terangkum dalam tabel berikut.

Tabel 2. Kabupaten/kota dengan persentase kenaikan dana perimbangan tertinggi dan terendah tahun 2013 dan 2014 (dalam juta rupiah)

\begin{tabular}{|c|c|c|c|c|c|c|c|}
\hline \multirow[t]{2}{*}{ KAB/KOTA } & \multicolumn{2}{|c|}{ Dana Perimbangan } & \multicolumn{2}{|c|}{$\begin{array}{c}\text { Perubahan } \\
(\Delta)\end{array}$} & \multirow{2}{*}{$\begin{array}{c}\begin{array}{c}\text { Dana } \\
\text { Perim- } \\
\text { bangan }\end{array} \\
2014\end{array}$} & \multicolumn{2}{|c|}{$\begin{array}{l}\text { Perubahan } \\
(\Delta)\end{array}$} \\
\hline & 2012 & 2013 & $\mathrm{Rp}$ & $\%$ & & $\mathrm{Rp}$ & $\%$ \\
\hline Kab. Bojonegoro & 1.195 .907 & 1.467 .842 & 271.935 & 0,23 & - & - & - \\
\hline Kota Malang & 784.555 & 828.123 & 43.569 & 0,06 & - & - & - \\
\hline Kab. Bojonegoro & 1.195 .907 & 1.467 .842 & 271.935 & 0,23 & 1.717 .168 & 249.326 & 0,17 \\
\hline Kab. Sumenep & 1.034 .573 & 1.171 .286 & 136.714 & 0,13 & 1.208 .218 & 36.931 & 0,03 \\
\hline
\end{tabular}

Sumber: Data Dana Perimbangan Jawa Timur, DJPK tahun 2012-2014, data diolah.

Persentase peningkatan dana perimbangan terbanyak yang diterima kabupaten/kota yang ada di Jawa Timur tahun 2013 adalah di kabupaten Bojonegoro dengan peningkatan sebesar $23 \%$ dan peningkatan penerimaan dana perimbangan terendah diterima di kota Malang yang hanya meningkat sebesar $6 \%$.

Ditahun selanjutnya yaitu tahun 2014 kabupaten Bojonegoro juga menerima dana perimbangan dengan kenaikan tertinggi diantara kabupaten/kota yang ada di Jawa Timur dengan kenaikan 17\% dari tahun 2013, kabupaten Sumenep menerima peningkatan dana perimbangan terendah yang hanya meningkat sebesar 3\% dari tahun sebelumnya.

Pendapatan asli daerah merupakan cerminan dari kemandirian suatu daerah, semakin tinggi kontribusi pendapatan asli daerah terhadap penerimaan daerah, maka tingkat kemandirian suatu daerah semakin tinggi. Persentase jumlah pendapatan asli daerah terhadap penerimaan daerah Jawa Timur terus bertambah dari tahun ke tahunnya (2012-2014) namun masih sangat minim, yaitu hanya $13,64 \%$ dari total pendapatan Jawa Timur pada tahun 2012, tahun 2013 persentasenya naik $0,88 \%$ menjadi 
$14,52 \%$ dan ditahun berikutnya yaitu tahun 2014 naik $1,66 \%$ dengan total $16,17 \%$ terhadap total pendapatan Jawa Timur. Berikut disajikan tabel kabupaten dan kota di Jawa
Timur dengan persentase kenaikan pendapatan asli daerah tertinggi dan terendah tahun 2013,2014 yang terangkum dalam tabel berikut.

Tabel 3. Kabupaten dan kota dengan persentase kenaikan pendapatan asli daerah tertinggi dan terendah tahun 2013 dan 2014 (dalam juta rupiah)

\begin{tabular}{lrrrrrrr}
\hline \multirow{2}{*}{ KAB/KOTA } & \multicolumn{2}{c}{$\begin{array}{c}\text { Pendapatan Asli } \\
\text { Daerah }\end{array}$} & \multicolumn{2}{c}{ Perubahan $(\Delta)$} & PAD & \multicolumn{2}{c}{ Perubahan $(\Delta)$} \\
\cline { 2 - 8 } & 2012 & 2013 & $\mathrm{Rp}$ & $\%$ & 2014 & $\mathrm{Rp}$ & $\%$ \\
\hline Kab. Mojokerto & 107.074 & 190.236 & 83.162 & 77,66 & - & - & - \\
\hline Kota Blitar & 54.987 & 56.370 & 1.383 & 2,52 & - & - & - \\
\hline Kab. Nganjuk & 98.689 & 118.057 & 19.3359 & 19.62 & 201.045 & 82.988 & 70,29 \\
\hline Kab. Bojonegoro & 135.697 & 195.973 & 60.276 & 44,42 & 196.055 & 82 & 0,04 \\
\hline
\end{tabular}

Sumber: Data Pendapatan Asli Daerah Jawa Timur, DJPK tahun 2012-2014, data diolah.

Pendapatan asli daerah Kabupaten Mojokerto meningkat $77,66 \%$ ditahun 2013 dan peningkatan ini merupakan peningkatan yang tertinggi diantara kabupaten dan kota yang ada di Jawa Timur di tahun 2013, peningkatan pendapatan asli daerah terendah pada kabupaten dan kota di Jawa Timur tahun 2013 adalah yang berhasil dikumpulkan oleh Kabupaten Blitar dengan peningkatan sebesar $2,52 \%$ dari tahun sebelumnya. Ditahun 2014 Kabupaten Nganjuk meningkatkan pendapatan asli daerahnya hingga
$70,29 \%$ dari tahun sebelumnya dan ini merupakan kenaikan pendapatan asli daerah tertinggi diantara kabupaten dan kota yang ada di Jawa Timur tahun 2014 dan peningkatan pendapatan asli daerah terendah adalah kabupaten Bojonegoro yang hanya meningkat 82 juta rupiah saja dari tahun sebelumnya atau setara dengan kenaikan 0,04\%. Untuk lebih lengkapnya persentase perubahan pendapatan asli daerah pada 38 kabupaten dan kota di Jawa Timur digambarkan di lampiran. 
Data dari Direktorat Jenderal tahunnya (2012-2014). Berikut Perimbangan Keuangan Republik disajikan tabel persentase belanja Indonesia mengungkapkan bahwa nilai dari belanja daerah 38 daerah tertinggi dan terendah tahun kabupaten dan kota yang ada di Jawa Timur selalu bertambah dari setiap 2013,2014 kabupaten dan kota di Jawa Timur yang terangkum dalam tabel 4.

Tabel 4. Kabupaten dan kota dengan persentase kenaikan belanja daerah tertinggi dan terendah tahun 2013 dan 2014 (dalam juta rupiah)

\begin{tabular}{|c|c|c|c|c|c|c|c|}
\hline \multirow{2}{*}{ KAB/KOTA } & \multicolumn{2}{|c|}{ Belanja Daerah } & \multicolumn{2}{|c|}{ Perubahan $(\Delta)$} & \multirow{2}{*}{$\begin{array}{c}\begin{array}{c}\text { Belanja } \\
\text { Daerah }\end{array} \\
2014\end{array}$} & \multicolumn{2}{|c|}{ Perubahan $(\Delta)$} \\
\hline & 2012 & 2013 & Rp (juta) & $\%$ & & Rp (juta) & $\%$ \\
\hline Kabupaten Nganjuk & 1.207 .703 & 1.621 .852 & 414.149 & 34,3 & - & - & - \\
\hline Kabupaten Trenggalek & 1.039 .168 & 1.043 .294 & 4.132 & 0,4 & - & - & - \\
\hline Kota Batu & 482.785 & 565.765 & 82.979 & 17,2 & 761.572 & 195.807 & 34,6 \\
\hline Kabupaten Nganjuk & 1.207 .703 & 1.621 .852 & 414.149 & 34,3 & 1.625 .317 & 3.465 & 0,2 \\
\hline
\end{tabular}

Sumber:Data Belanja Daerah kabupaten/kota di Jawa Timur, DJPK tahun 20122014, data diolah.

Kenaikan belanja daerah tertinggi yang dikeluarkan diantara 38 kabupaten dan kota yang ada di Jawa Timur tahun 2013 adalah Kabupaten Nganjuk dengan kenaikan belanja daerah sebesar 414.149 juta rupiah dari tahun sebelumnya atau setara dengan kenaikan sebesar $34,3 \%$ sedangkan pada tahun 2014 kenaikan belanja daerah tertinggi adalah kota batu, yang jumlah belanjanya naik sebesar 195.807 juta rupiah atau setara dengan kenaikan $34,6 \%$. Sedangkan kenaikan belanja daerah terendah tahun 2013 adalah kabupaten Trenggalek dengan kenaikan belanja daerah hanya 4.132 juta rupiah atau setara dengan $0,4 \%$. Kenaikan belanja daerah terendah pada tahun 2014 adalah kabupaten Nganjuk dengan kenaikan sebesar 3.465 juta rupiah atau $0,2 \%$.

Hasil Uji Statistik

Dari tiga teknik yang digunakan diatas (uji Chow, uji Hausman dan uji Lagrange Multiplier), dapat disimpulkan bahwa metode yang paling tepat dalam penelitian ini adalah Fixed Effects. 
Hasil pengolahan data Fixed Effect menunjukkan bahwa hasil persamaan regresi data panel antara dana perimbangan dan pendapatan asli daerah terhadap belanja daerah pemerintah kabupaten dan kota di Jawa Timur adalah sebagai berikut : $\mathrm{Y}_{\mathrm{it}}=-178220,6+1,389814 \mathrm{X} 1+$ $1,658656 \times 2+e_{t}$

Pembahasan Hasil Pengaruh Dana Perimbangan Terhadap Belanja Daerah Pemerintah Kabupaten dan Kota di Jawa Timur.

Dana Perimbangan berpengaruh signifikan positif terhadap belanja daerah pemerintah kabupaten dan kota di Jawa Timur secara parsial. Hal ini sesuai dengan penelitian yang telah dilakukan oleh Maimunah (2006) yang menyatakan bahwa Besarnya nilai DAU mempengaruhi nilai belanja Daerah (pengaruh positif). Pengaruh positif yang ditimbulkan oleh dana perimbangan terhadap belanja daerah adalah apabila jumlah dana perimbangan naik, maka alokasi untuk belanja daerah juga akan bertambah jumlahnya, sedangkan penurunan dari dana perimbangan akan menurunkan alokasi belanja daerah pemerintah kabupaten dan kota di Jawa Timur.

Meskipun dana perimbangan berpengaruh positif terhadap belanja daerah, akan tetapi dana perimbangan menyebabkan suatu daerah tidak bisa mandiri, karena masih menggantungkan pada pemerintah pusat. Sedangkan dalam otonomi daerah, masing-masing daerah dihimbau agar dapat memaksimalkan pendapatan asli daerahnya karena pendapatan asli daerah merupakan cerminan dari kemandirian suatu daerah.

Pengaruh Pendapatan Asli Daerah Terhadap Belanja Daerah Pemerintah Kabupaten dan Kota di Jawa Timur.

Secara simultan variabel dana perimbangan berpengaruh signifikan positif terhadap belanja daerah pemerintah kabupaten dan kota di Jawa Timur. Positifnya hubungan antara dana perimbangan dan belanja daerah menandakan apabila jumlah dana perimbangan yang diberikan oleh pemerintah pusat naik, maka alokasi belanja daerah akan naik, hal tersebut berlaku sebaliknya apabila dana perimbangan yang diterima pemerintah kabupaten dan kota di 
Jawa Timur turun maka alokasi untuk belanja daerah akan turun. Hasil tersebut sama dengan penelitian dari Prakosa (2004), Syukriy dan Halim (2003) dalam Rahmawati (2010) yang menyatakan bahwa pendapatan (terutama pajak) akan mempengaruhi Anggaran Belanja Pemerintah Daerah dan dikenal dengan nama tax spend hypothesis.

\section{Secara}

bersama-sama

variabel dana perimbangan dan pendapatan asli daerah berpengaruh signifikan positif terhadap belanja daerah pemerintah kabupaten dan kota di Jawa Timur. Pengaruh positif tersebut menandakan bahwa, apabila dana perimbangan naik dan pendapatan asli daerah naik, maka alokasi untuk belanja daerah juga akan bertambah jumlahnya, sedangkan penurunan dari dana perimbangan dan pendapatan asli daerah akan menurunkan alokasi belanja daerah Pemerintah daerahkabupaten dan kota di Jawa Timur.

Hal ini sesuai dengan penelitian yang telah dilakukan oleh Lestari, Bagia dan Jana (2015) dan Budiarti (2014) yang menyatakan bahwa dana perimbangan dan pendapatan asli daerah berpengaruh terhadap belanja langsung serta penelitian dari Rahmawati (2012), yang menegaskan bahwa pendapatan asli daerah dan dana alokasi umum mempunyai pengaruh yang signifikan terhadap belanja tidak langsung.

\section{PENUTUP}

Regresi data panel dalam penelitian ini menggunakan teknik Fixed Effect dan diketahui persamaan regresi data panel untuk analisis ini adalah $\mathrm{Y}_{\mathrm{it}}=-178220,6+1,389814$ $\mathrm{X} 1+1,658656 \mathrm{X} 2+\mathrm{ei}_{\mathrm{t}}$. Dana perimbangan berpengaruh signifikan positif terhadap belanja daerah pemerintah kabupaten dan kota di Jawa Timur, pendapatan asli daerah berpengaruh signifikan positif terhadap belanja daerah pemerintah kabupaten dan kota di Jawa Timur, dana perimbangan dan pendapatan asli daerah berpengaruh signifikan positif terhadap belanja daerah pemerintah kabupaten dan kota di Jawa Timur.

Pemerintah daerah Jawa Timur perlu untuk meningkatkan 
pendapatan asli daerahnya dengan cara mengintensifkan pemungutan pajak dan retribusi daerah, serta meningkatkan kinerja BUMD agar semua pengeluaran pemerintah daerah yang terkait dengan program kerja, baik itu secara langsung maupun tidak langsung dapat dibiayai dari pendapatan asli daerah, supaya Jawa Timur menjadi Provinsi yang mandiri, artinya dalam membiayai pengeluarannya tidak menggantungkan kepada dana perimbangan yang saat ini jumlahnya lebih besar daripada pendapatan asli daerahnya. Karena dalam kenyataannya belanja konsumtif Jawa Timur lebih besar daripada belanja produktif, maka pemerintah daerah harus memperbaiki manajemen belanja daerahnya.

\section{DAFTAR PUSTAKA}

Anonymous, 2004. Undang-undang

Republik Indonesia No. 32

Tahun $2004 \quad$ Tentang

Pemerintahan Daerah. Jakarta: s.n.

Anonymous, 2004. Undang-undang Republik Indonesia Nomor 33 Tahun $2004 \quad$ tentang
Perimbangan Keuangan

Antara Pemerintah Pusat dan Daerah. Jakarta: s.n.

Budiarti, P., 2014. Pengaruh Pendapatan Asli Daerah (PAD) dan Dana Alokasi Umum (DAU) terhadap Struktur Belanja Daerah (Studi Pada Pemerintah Kabupaten/Kota di Jawa Timur). Jurnal Jurusan Akuntansi Fakultas Ekonomi dan Bisnis Universitas Brawijaya.

Keuangan, K., 2011. Deskripsi dan Analisis APBD 2011, Jakarta: Direktorat Jenderal Perimbangan Keuangan.

Keuangan, K., 2012. Realisasi APBD Jawa Timur Tahun 2012, Jakarta: Direktorat Jenderal Perimbangan Keuangan.

Keuangan, K., 2013. Realisasi APBD Jawa Timur Tahun 2013, Jakarta: Direktorat Jenderal Perimbangan Keuangan.

Keuangan, K., 2014. Realisasi APBD Jawa Timur Tahun 2014, Jakarta: Direktorat Jenderal Perimbangan Keuangan.

Lestari, N. N. S. A., Bagia, I. W. \& Jana, G. P. A. S., 2015. 
Pengaruh

Anggaran

Pendapatan Belanja Negara

(APBN) terhadap Belanja

Langsung pada Pemerintah

Daerah Kabupaten/Kota. $e$ -

Journal Bisma Universitas

Pendidikan Ganesha, Volume

Volume. 3.

Maimunah, Mutiara., 2006. Flypaper

Effect Pada Dana Alokasi

Umum dan Pendapatan Asli

Daerah terhadap Belanja

Daerah pada Kabupaten/Kota

di Pulau Sumatera. Simposium

Nasional Akuntansi IX.
Rahmawati, N. I., 2010. Pengaruh Pendapatan Asli Daerah dan Dana Alokasi Umum terhadap Alokasi Belanja Daerah (Studi pada Pemerintah Kabupaten/Kota di Jawa Tengah). Skripsi Universitas Diponegoro Semarang.

Tuasikal, A., 2008. Pengaruh DAU,DAK, PAD dan PDRB terhadap Belanja Modal Pemerintah Daerah Kabupaten/Kota di Indonesia. Jurnal Telaah \& Riset Akuntansi, Volume Volume. 1 Nomor. 2, pp. 142-155. 
Pengaruh Dana Perimbangan Dan Pendapatan Asli Daerah...............(Poppy Eliza) 